\begin{tabular}{|c|c|c|}
\hline Dinamika Journal, Vol. 1 No. 4, 2019 \\
ISSN ONLINE : 2686-2158
\end{tabular}

\title{
PEMBERDAYAAN WIRAISTRI DALAM PENGEMBANGAN HOME INDUSTRY SABUN HERBAL RAMAH LINGKUNGAN BERBASIS KELAPA SAWIT (Elais ginesiss Jacq)
}

\author{
Sri Dewi Wahyundaru ${ }^{1 *}$, Rina Wijayanti²) \\ ${ }^{1}$ Fakultas Ekonomi, Universitas Islam Sultan Agung, Semarang, Indonesia \\ ${ }^{2}$ Program Studi Farmasi Fakultas Kedokteran, Universitas Islam Sultan Agung, Semarang, \\ Indonesia \\ *Corresponding author: sridewi@unissula.ac.id
}

Received 9 August 2019; Accepted 27 November 2019; Available online 11 December 2019

\begin{abstract}
Abstrak
Jasa laundry di sekitar Kelurahan Plombokan Kecamatan Semarang Utara Kota Semarang Provinsi Jawa Tengah saat ini terus meningkat dikarenakan adanya potensi usaha dari laundry di dalam perkembangan aktivitas masyarakat, mengingat letak Kelurahan Plombokan sangat strategis yang berada di dekat Pusat Pemerintahan Kota Semarang dan beberapa sekolah. Pengembangan produk sabun herbal yang ramah lingkungan perlu daya dukung baik sarana, prasarana, organisasi, Sumber Daya Manusia maupun pemasaran sebagai strategi untuk meningkatkan keunggulan kompetitif. Tujuan kegiatan pengabdian masyarakat ini adalah untuk meningkatkan pengetahuan dan ketrampilan wiraistri (wirausaha istri) dalam pembuatan, pembukuan, serta pemasaran sabun herbal ramah lingkungan berbahan kelapa sawit (Elais ginesiss Jacq). Metode pelaksanaan kegiatan meliputi aktivitas berbasis kelompok yang dilakukan secara menyeluruh sehingga mampu mengakomodir seluruh aspek usaha dari peningkatan mindset wirausaha, tersedianya sarana dan prasarana guna menjalankan usaha dari pengembangan manajemen pemasaran melalui pelatihan dan pendampingan produk sabun herbal. Hasil evaluasi pelatihan dan pendampingan menunjukkan peningkatan pengetahuan dan ketrampilan wiraistri dalam pembuatan sabun herbal ramah lingkungan.
\end{abstract}

Kata-kata kunci / Keywords: wiraistri, sabun herbal, ramah lingkungan, Kelapa sawit, Elais ginensiss Jacq

\begin{abstract}
A business of laundry service around Plombokan village, North Semarang district, Semarang City, Central Java province now increasing, due to potential of laundry business in development community activities. Kelurahan Plombokan also strategically located close to central government and schools area. However, the expansion of eco friendly herbal soap needs supporting system in equipment, organization, human resources and marketing as strategy to increase competitive excellence. This social program aims to increase the wiraistri or wifepreneur's knowledge and skill of creating, administrative, and marketing
\end{abstract}


deal with eco friendly herbal soap made of palm oil (Elais ginesiss Jacq). Implementation method of this project consist of group based activity done comprehensively lead to accommodate all aspect of business from increasing entrepreneurship mindset, availability of facilities. This training and accompaniment lead to apply the business from aspect of development of marketing management. The result shows that the wiraistri or wifepreneur's knowledge and skill increased.

Keywords : wiraistri, herbal soap, eco friendly, Palm oil, Elais ginensiss Jacq

\section{PENDAHULUAN}

Kelurahan Plombokan Kecamatan Semarang Utara Kota Semarang terletak di lokasi yang sangat strategis berada di dekat Pusat Pemerintahan Kota Semarang dan beberapa sekolah sehingga berdampak pada tumbuhnya roda perekonomian berkembang pesat. Banyaknya konsumen dari penduduk sekitar, mahasiswa, serta pegawai yang hanya sedikit memiliki waktu luang menyebabkan semakin meningkatnya usaha di bidang jasa laundry. Jumlah usaha laundry yang berada di sekitar Kelurahan Plombokan sekitar 20. Perkembangan jasa laundry tersebut memiliki pengaruh negatif terhadap kesehatan lingkungan, yakni meningkat pula limbah deterjen. Potensi Sumber Daya Manusia yang dimiliki oleh Kelurahan Plombokan di mana sebagian besar masyarakat adalah istri-istri pedagang, wirausaha kecil menengah, buruh bangunan, dan buruh industri yang masih banyak waktu luang dapat diberdayakan dalam kegiatan pengembangan usaha kreatif, sekaligus sebagai upaya mengurangi dampak negatif penggunaan sabun berbahan kimia. Dengan besarnya jumlah istri karyawan yang produktif secara ekonomis dengan usaha mikro berupa jasa laundry, tetapi belum memiliki ketrampilan dan pengetahuan yang memahami proses produksi sabun herbal berbasis Elais ginensiss Jacq, yang tergabung sebagai Mitra Wiraistri (Wirausaha Istri) Karyawan Kelompok ANISA dan Kelompok SEHAT, diharapkan mampu bersinergi untuk bersama-sama mengembangkan usaha produktif yang bermanfaat bagi ekonomi keluarga.

Kenyataan ini mendorong pentingnya kelompok usaha bersama yang mengembangkan produk sabun herbal dengan bahan baku utama berbasis Elais ginensiss Jacq guna menjaga keseimbangan lingkungan dan memelihara kesehatan masyarakat. Produk ini diharapkan dapat menjadi produk unik bagi Pemerintah Kota Semarang yang memprioritaskan program unggulan yaitu program sabun herbal yang ramah lingkungan, sehat dan kreatif berbasis herbal Elais ginensiss Jacq. Hal ini sesuai dengan visi Kota Semarang yaitu Semarang sebagai Kota perdagangan dan jasa yang berbudaya menuju Masyarakat sejahtera. Sabun herbal berbasis Elais ginensiss Jacq diharapkan mampu menjadi produk yang lebih unggul dibanding deterjen berbahan kimia. Produksi surfaktan dari bahan baku Elais ginensiss Jacq prospeknya sangat cerah, sebab nilai tambahnya 20 kali lipat lebih tinggi dibandingkan dengan harga CPO (Crude Palm Oil) (Purwaningtyas dan Pramudono, 2009). Surfaktan yang dibuat dari minyak nabati bersifat mudah terurai secara biologi (biodegradable) sehingga tidak mencemari lingkungan. Kesinambungan pengadaan bahan bakunya terjamin karena minyak nabati merupakan sumber daya alam yang dapat diperbaharui (renewable).

Sebagai sabun yang aman, keberadaan sabun herbal berbasis Elais ginensiss Jacq ini diharapkan nantinya sangat digemari di kalangan masyarakat. Sabun ramah lingkungan diharapkan menjadi icon di semua kalangan masyarakat Kota Semarang, di mana usaha sabun sedang maju pesat di semua daerah. Potensi usaha sabun tidak bisa dipandang sebelah mata dikarenakan setidaknya ada 4 sektor laundry yang cukup besar. Menurut data dari Ketua Umum Asosiasi Profesi Laundry (APLI) Wasono Raharjo, ke empat sektor laundry tersebut 
adalah Laundry Hotel, Laundry Rumah Sakit, Laundry Komersil, serta Laundry Garmen. Kehadiran sabun herbal halal berbasis Elais ginensiss Jacq berpotensi besar menjadi solusi sebagai sabun sehat dengan permintaan tinggi sehingga usaha ini memiliki peluang potensial jika terus dikembangkan.

Pendampingan dalam hal pengelolaan dan pemasaran sabun herbal berbasis Elais ginensiss Jacq diharapkan membuka mindset dari istri karyawan di Kelurahan Plombokan agar usaha bisa lebih berkembang, bagaimana menjalankan usaha serta berbisnis tetap berlangsung dan survive. Penjualan produk sabun herbal yang ramah lingkungan, baik untuk konsumen rumah tangga maupun pada jasa laundry sebagai upaya meningkatkan kesadaran akan pentingnya sabun yang ramah lingkungan. Agar lebih berdaya jual tinggi, finishing dari kegiatan produksi sabun adalah pendampingan dalam hal pengepakan (packaging) yang menarik dan berlabel yang memuat informasi keunggulan produk sabun herbal dibanding kompetitor. Teknik pemasaran yang baik juga diperlukan guna menunjang keberhasilan penjualan sabun herbal. Pendampingan dalam hal kegiatan pemasaran melalui media online dilakukan untuk sarana periklanan, yang merupakan salah satu alat marketing untuk memperlihatkan dan menjual produk dari perusahaan kepada masyarakat tertentu (Supriyono, 2010).

\section{METODE PELAKSANAAN}

Upaya untuk menyelesaikan permasalahan yang dihadapi Mitra, maka dapat diberikan solusi sesuai dengan priorotas permasalahan sebagai berikut :

1. Produksi sabun herbal berbahan Elais ginensiss Jacq yang memenuhi standar uji evaluasi sediaan, bermutu baik dari segi kualitas maupun kuantitas. Produk sabun herbal berbahan Elais ginensiss Jacq yang bersifat mudah terurai secara biologi (biodegradable) sehingga tidak mencemari lingkungan.

2. Mitra Wiraistri perlu diberdayakan dan diorganisir sebagai upaya pengembangan produk sabun herbal halal berbasis Elais ginensiss Jacq yang ramah lingkungan dan ramah kesehatan.

3. Mitra Wiraistri perlu ditanamkan jiwa kewirausahaan, serta pemahaman mengenai potensi sabun herbal halal Elais ginensiss Jacq sebagai antibakteri yang memenuhi standar uji evaluasi sediaan.

4. Mitra Wiraistri membutuhkan ketrampilan proses produksi hingga packaging sabun herbal halal Elais ginensiss Jacq yang sesuai standar formulasi sediaan, peningkatan pengetahuan manajemen usaha, promosi serta pemanfaatan media online untuk pengembangan trademark dan penjualan.

Metode pelaksanaan kegiatan sebagai solusi yang ditawarkan untuk mengatasi permasalahan Mitra meliputi pengembangan produk sabun herbal berbasis Elais ginensiss Jacq ramah lingkungan dilakukan dengan beberapa pendekatan yang dilakukan secara bersama-sama yaitu:

a. Berbasis kelompok wiraistri dalam pengembangan produk sabun herbal ramah lingkungan berbasis Elais ginensiss Jacq, seluruh kegiatan pengabdian masyarakat dilakukan kepada masyarakat menggunakan kelompok sebagi media belajar dan pendampingan, perencanaan dan memonitor serta evaluasi seluruh kegiatan pengabdian masyarakat.

b. Komprehensif, semua kegiatan pengabdian masyarakat dilakukan secara menyeluruh terkait dengan SDM, bahan baku, proses produksi ramah lingkungan sehat, packaging dan labeling, manajemen, serta teknik pemasaran yang dilakukan melalui pelatihan dan pendampingan tenaga penjualan. 
c. Berbasis potensi permintaan kebutuhan sabun untuk jasa laundry yang semakin meningkat di Kelurahan Plombokan Kecamatan Semarang Utara Provinsi Jawa Tengah, sehingga dapat menjadi produk unggulan yang memiliki ciri khas produk berupa sabun herbal berbasis Elais ginensiss Jacq.

Selanjutnya ketiga metode tersebut di atas diimplementasikan dalam 4 (empat) tahapan yaitu : (1) sosialisasi, (2) peningkatan kompetensi dan ketrampilan, (3) produksi atau pelaksanaan kegiatan, serta (4) monitoring dan evaluasi.

Khalayak sasaran dalam kegiatan pengabdian kepada masyarakat ini yaitu kelompok istri karyawan yang produktif secara ekonomi (usaha mikro berupa laundry), yang tinggal di Kelurahan Plombokan Kecamatan Semarang Utara Kota Semarang, Provinsi Jawa Tengah. Mitra dalam kegiatan pendampingan ini adalah Kelompok ANISA dan Kelompok SEHAT. Kedua Ketua Kelompok Mitra tersebut aktif dalam berbagai kegiatan kemasyarakatan dan berperan dalam mengarahkan dan memberikan informasi sekaligus penggerak Sumber Daya Manusia utamanya istri-istri karyawan, mengingat kebutuhan sabun laundry sangat banyak, sekaligus sebagai upaya memerangi dampak kesehatan lingkungan.

\section{HASIL DAN PEMBAHASAN}

Pelaksanaan kegiatan pengabdian kepada masyarakat ini menghasilkan beberapa hal di antaranya :

\section{Koordinasi Kegiatan dengan ketua Wiraistri ANISA dan SEHAT}

Koordinasi kegiatan dilaksanakan pad atanggal 8 Maret 2019. Koordinasi tersebut menghasilkan kesepakatan bahwa kegiatan pengabdian akan dilaksanakan pada tanggal 17 Maret 2019, yang diawali dengan penyuluhan tentang pengembangan home industry sabun herbal secara bersama-sama dengan kedua kelompok, yaitu Wiraistri ANISA dan Wiraistri SEHAT.

\section{Penyuluhan tentang Pengembangan Home Industry Sabun Herbal}

Kegiatan penyuluhan tentang pengembangan home industry sabun herbal dilaksanakan pada tanggal 17 Maret 2019. Kegiatan ini dirangkai dengan praktek langsung pembuatan sabun oleh kedua kelompok Wiraistri seperti yang tertuang pada Gambar 1 dan 2 .

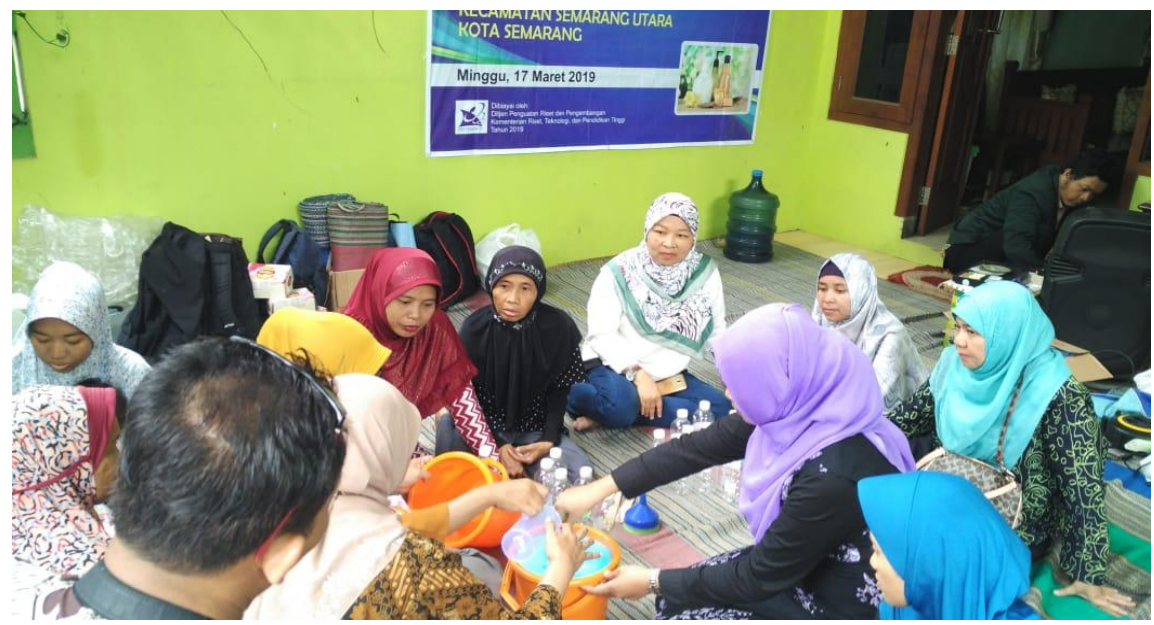

Gambar 1. Praktek pembuatan sabun herbal oleh kelompok Wiraistri

Materi pengembangan home industri sabun herbal meliputi apa saja dampak dari aktivitas mencuci, jenis-jenis detergent, bahan baku pembuatan detergent, contoh-contoh detergent yang aman, pemberdayaan ekonomi dengan cara membuat detergent sendiri, 
perbedaan dan keunggulan sabun herbal ramah lingkungan dibandingkan sabun lain, skema bisnis yang bisa dijalankan, serta ajakan kepada masyarakat untuk menghindari produk kapitalis, lebih peduli terhadap lingkungan serta kesehatan keluarga. Peserta terlihat antusias dan mulai terbuka mindset wirausahanya. Beberapa pertanyaan yang dilontarkan peserta menunjukkan bahwa penyuluhan berjalan interaktif.

Kegiatan penyuluhan diawali dengan pemberian pre-test kepada para peserta, dan diakhiri dengan post-test. Pertanyaan yang disampaikan meliputi materi-materi dampak dari aktivitas mencuci, jenis-jenis detergent, bahan baku pembuatan detergent, contoh-contoh detergent yang aman, serta perbedaan dan keunggulan sabun herbal ramah lingkungan dibandingkan sabun lain. Pre-test dan post-test ini digunalan sebagai alat ukur untuk mengetahui sejauh mana pemahaman peserta kegiatan pengabdian terhadap materi yang teleh disampaikan. Hasil score pre-test dan post-test tersaji pada Tabel 1.

Tabel 1. Hasil score pre-post test peserta kegiatan pengabdian kepada masyarakat

\begin{tabular}{ccc}
\hline No Kode Peserta & Score Pretest & Score Postest \\
\hline 1 & 80 & 100 \\
\hline 2 & 60 & 100 \\
\hline 3 & 80 & 80 \\
\hline 4 & 80 & 80 \\
\hline 5 & 80 & 100 \\
\hline 6 & 60 & 100 \\
\hline 7 & 60 & 100 \\
\hline 8 & 40 & 100 \\
\hline 9 & 40 & 100 \\
\hline 10 & 40 & 100 \\
\hline 11 & 40 & 80 \\
\hline 12 & 100 & 100 \\
\hline 13 & 60 & 100 \\
\hline 14 & 80 & 100 \\
\hline 15 & 40 & 80 \\
\hline 16 & 40 & 60 \\
\hline 17 & 40 & 80 \\
\hline 18 & 80 & 80 \\
\hline 19 & 60 & 80 \\
\hline Rerata \pm SD & $\mathbf{6 1 . 0 5} \pm \mathbf{1 9 . 4 0}$ & $\mathbf{9 0 . 5 3} \pm \mathbf{1 2 . 2 4} *$ \\
\hline
\end{tabular}

Keterangan : * $=$ terdapat perbedaan bermakna dengan score pretest $(\mathrm{P}<0,05)$

Data hasil score pretest dan posttest diolah untuk mengetahui apakah terdapat pengaruh pemberian materi terhadap tingkat pemahaman dan pengetahuan peserta penyuluhan. Dari hasil olah data maka diketahui bahwa terdapat perbedaan bermakna pada score pretest dan posttest $(\mathrm{Sig}=0,000<0,005)$. Hal ini menunjukkan bahwa pemberian materi dapat meningkatkan pengetahuan dan pemahaman peserta penyuluhan. Mitra pada awalnya belum mengerti dan memahami pengetahuan tentang dampak dari aktivitas mencuci, jenis-jenis detergent, bahan baku pembuatan detergent, contoh-contoh detergent yang aman, serta perbedaan dan keunggulan sabun herbal ramah lingkungan dibandingkan sabun lain. Hal ini terlihat dari score pretest (rerata 61.05). Setelah diberikan materi, terlihat bahwa tingkat pemahaman dan pengetahuan Mitra mengalami kenaikan, hal ini ditunjukkan dengan hasil score pretest yang mengalami peningkatan (rerata 90.53). 


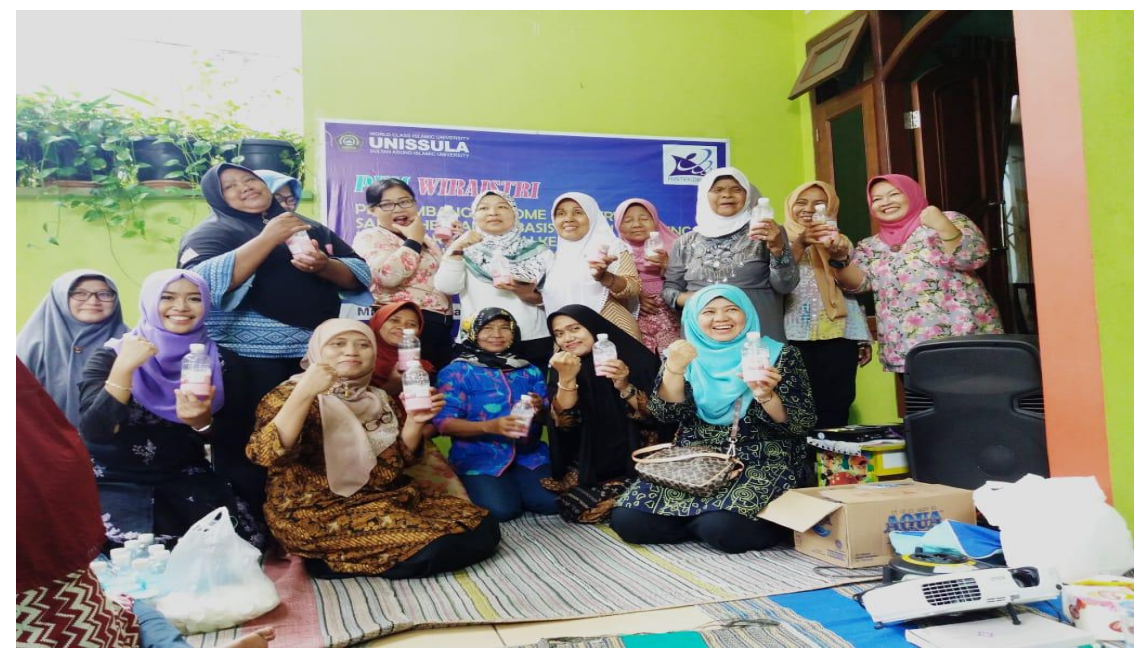

Gambar 2. Kelompok Wiraistri menunjukkan sabun herbal hasil pelatihan

\section{Pendampingan Manajemen Pembukuan dan Pemasaran online}

Langkah selanjutnya adalah membekali kelompok Wiraistri ANISA dan SEHAT dalam melaksanakan administrasi pembukuan. Kegiatan tersebut dilaksanakan pada tanggal 27 Juli 2019. Pada kegiatan ini masing-masing kelompok Wiraistri diberikan paket manajemen pembukuan. Materi yang disampaikan berupa Laporan Buku Kas, Perhitungan Laba Rugi, serta penerapan Ilmu Keuangan Akuntansi dalam manajemen pembukuan. Gambar kegiatan pendampingan manajemen pembukuan tersaji pada Gambar 3. Langkahlangkah Manajemen Pembukuan tersebut meliputi :

1. Mencatat semua transaksi, yaitu transaksi :

A. Mencatat Pengeluaran

a. Pembelian bahan baku sabun

b. Biaya - biaya pembelian bahan baku sabun

c. Pengeluaran semua perlengkapan yang dibutuhkan, misal : alat - alat Ember, Botol

B. Mencatat Penerimaan

Yaitu mencatat berapa jumlah yang diterima dari hasil penjualan sabun tersebut, dan penerimaan dari hasil laundry

2. Memasukkan transaksi pengeluaran dan penerimaan secara urut kejadian transaksi, dan dihitung langsung saldo akhir

3. Setiap Minggu dicek jumlah Saldo Akhir

4. Pencatatan berapa Keuntungan / Laba yang didapat atau Kerugian

5. Apabila sudah bertambah besar jumlah Laba, maka bisa menambah Modal 


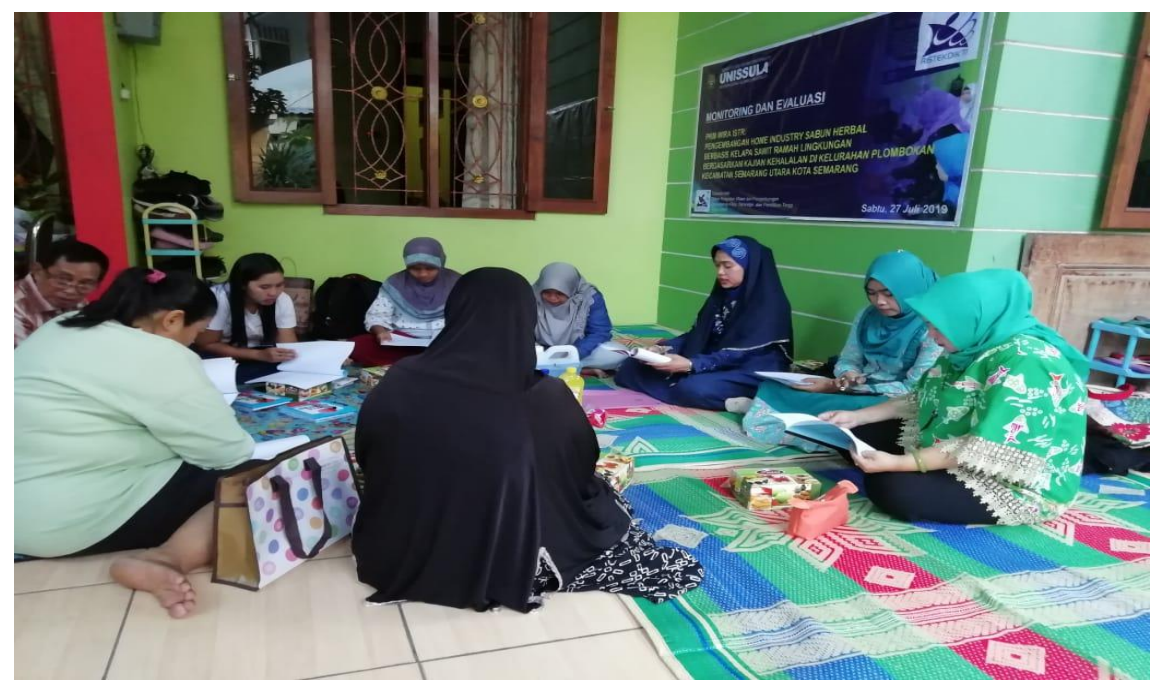

Gambar 3. Kegiatan pendampingan manajemen pembukuan

Kegiatan pendampingan manajemen pembukuan dirangkai dengan pendampingan pemasaran secara online. Melalui kegiatan ini diharapkan produk sabun dapat dipasarkan secara lebih luas melalui blogspot.

\section{Monitoring dan Evaluasi}

Langkah evaluasi yang ditempuh dalam kegiatan pengabdian masyarakat ini adalah monitoring melalui kehadiran, pre-post test yang menunjukkan perbedaan bermakna $(\mathrm{P}<0,05)$, produksi sabun yang meningkat $(10 \%$ per bulan), serta peningkatan penjualan sabun $(10 \%$ per bulan).

\section{KESIMPULAN}

Kegiatan pengabdian masyarakat ini secara keseluruhan dapat disimpulkan telah berjalan dengan baik, animo peserta pelatihan sangat tinggi, serta pengetahuan masyarakat yang meningkat (dilihat dari hasil analisis data pretest dan postest yang berbeda bermakna), ketrampilan masyarakat meningkat, serta pemberdayaan secara ekonomi menunjukkan peningkatan yang positif.

\section{UCAPAN TERIMA KASIH}

Ucapan terima kasih disampaikan kepada Direktorat Riset dan Pengabdian Masyarakat Direktorat Jenderal Riset dan Pengembangan Kementerian Riset, Teknologi, dan Pendidikan Tinggi yang telah mendanai kegiatan ini melalui Skema Program Kemitraan Masyarakat tahun 2019. Hal yang sama disampaikan kepada LPPM UNISSULA serta seluruh anggota kelompok Wiraistri Sehat dan Anisa Kelurahan Plombokan, Kecamatan Semarang Utara, Kota Semarang, Provinsi Jawa Tengah atas kerjasamanya dalam pelaksanaan kegiatan ini.

\section{DAFTAR PUSTAKA}

A.Shim, Terence. 2003. Periklanan Promosi, Aspek Tambahan Komunikasi Pemasaran Terpadu. Erlangga, Jakarta.

Anonim. 2016. Peraturan Walikota Semarang nomor 9 Tahun 2015 tentang Rencana Kerja Pemerintah Daerah (RKPD) Kota Semarang tahun 2016

Asyhari. 2014. Strategi Pengembangan Ekonomi Kreatif. EF Press DIGIMEDIA, Semarang. 
Badan Pusat Statistik. 2016. Kecamatan Semarang Utara Dalam Angka, Badan Pusat Statistik Kota Semarang.

Badan Pusat Statistik. 2016. Kota Semarang dalam Angka. Badan Pusat Statistik Kota Semarang.

Lutfi, Mustofa; Setiawan, Sigit; Nugroho, A. Wahyuanto. 2010. Rancang Bangun Perajang Ubi Kayu Horizontal. Jurnal Rekayasa Mesin Vol.1, No. 2: 41-46.

Purwaningtyas. E. F., Pramudono, B. 2009. Pembuatan Surfaktan Polyoxyethylene dari Minyak Sawit : Pengaruh Rasio Mono-Digliserida dan Polyethylen Glikol; Reaktor; Vol. 12 No. 3; Juni 2009; Hal. 175-182.

Rakhmat Supriyono. 2010. Desain Komunikasi Visual. Yogyakarta, Penerbit Andi.

Raliby, Osman; Rusdjijati, Retno. 2010. Perancangan Alat Pengering Kerupuk Dengan Memanfaatkan Gas Buang Dari Proses Produksi pada Industri Pembuatan Kerupuk. Prosiding Seminar Nasional Sains dan Teknologi. Fakultas Teknik Universitas Wahid Hasyim Semarang.

Suparmi. 2013. IbM Kalurahan Penggaron Lor Melalui Pemberdayaan PKK Dalam Pembuatan Jajanan Sehat Dengan Pewarna Alami. Semarang

Suryana. 2013. Ekonomi Kreatif : Ekonomi Baru : Mengubah Ide dan Menciptakan peluang. Salemba Empat, Jakarta.

Ulrich. 20013. Product Design and Development 3rd Ed. Mc. Graw Hill, Singapore. 